\title{
Two new genera of Encyrtidae (Hymenoptera, Chalcidoidea) with reduced ovipositor sheaths
}

\author{
Serguei A. Simutnik', Evgeny E. Perkovsky', \\ Mykola R. Khomych², Dmitry V. Vasilenko ${ }^{3,4}$
}

I I.I. Schmalhausen Institute of Zoology, National Academy of Sciences of Ukraine, Kiev, 01601 Ukraine 2 Vil. Voronky, Varash Distr., Rovno Region, Rovno, 34330 Ukraine 3 Borissiak Paleontological Institute, Russian Academy of Sciences, Moscow, 117647 Russia 4 Cherepovets State University, Cherepovets, Vologda Region, 162600 Russia

Corresponding author: Serguei A. Simutnik (simutnik@gmail.com)

Academic editor: Petr Janšta | Received 10 December 2021 | Accepted 14 February 2022 | Published 28 February 2022

http://zoobank.org/B7481032-36C1-4517-830D-9CDC3DB7C5DA

Citation: Simutnik SA, Perkovsky EE, Khomych MR, Vasilenko DV (2022) Two new genera of Encyrtidae (Hymenoptera, Chalcidoidea) with reduced ovipositor sheaths. Journal of Hymenoptera Research 89: 47-60. https:// doi.org/10.3897/jhr.89.79180

\begin{abstract}
Archaeocercoides puchkovi Simutnik, gen. et sp.nov., and Rovnopositor voblenkoi Simutnik, gen. et sp.nov., are described and illustrated based on female specimens from late Eocene Rovno amber. Like most previously described Eocene Encyrtidae, the new taxa differ from the majority of extant encyrtids by the apical or nearly apical position of the cerci, the short radicle, and the long marginal vein of the forewing. Both new genera are characterized by a strongly reduced ovipositor sheaths but long and upwardly bent ovipositor stylets (in the "ovipositing position"), a stigmal vein with a long uncus, and the absence of a filum spinosum. The new genera differ from each other in the width of frontovertex, the location of the cerci, and the lengths of funicular segments and marginal vein. A. puchkovi was fossilized near a Coccoidea crawler.
\end{abstract}

\section{Keywords}

Cerci, Coccoidea, radicle, Rovno amber, syninclusion, valvulae of ovipositor

Copyright Serguei A. Simutnik et al. This is an open access article distributed under the terms of the Creative Commons Attribution License (CC BY 4.0), which permits unrestricted use, distribution, and reproduction in any medium, provided the original author and source are credited. 


\section{Introduction}

An extremely apical or near apical position of the cerci is very rare among extant encyrtids, but is seen in most extinct ones (Simutnik and Perkovsky 2006, 2018a; Simutnik 2021; Simutnik et al. 2021a, 2021b). Two new fossil encyrtid genera with this character state are described below.

This brings the number of Rovno amber hymenopteran genera unknown in Baltic amber to 28 of 90 , i.e., $31 \%$ (our unpublished data). This includes 22 of $52(42.3 \%)$ non-ant hymenopterans genera and 46 of 69 of non-ant species (66.7\%) (Perkovsky 2018; Manukyan 2019; Martynova et al. 2019; Perkovsky et al. 2020; Simutnik and Perkovsky 2020; Simutnik et al. 2020, 2021b; Belokobylskij et al. 2021; Colombo et al. 2021a, b, c; Manukyan and Zhindarev 2021). Baltic amber species from large arthropod orders and suborders reported from Rovno amber vary from $32.4 \%$ for Trichoptera (Perkovsky 2017; Melnitsky et al. 2021a, 2021b, 2021c), 24\% for Nematocera (Gilka et al 2021) and 15\% for Coleoptera (Telnov et al. 2021; KirichenkoBabko et al. 2022; Perkovsky et al. 2022); 33\% of non-ant hymenopterans common for Baltic and Rovno amber is close to the ratio for caddisflies (Trichoptera), which have been extensively studied (e.g., Melnitsky et al. 2021c and references therein). As more than 300 insect species have been described from Rovno amber (Martynov et al. 2021), this supports an independent origin of its fauna.

\section{Material and methods}

The studied specimens are housed in the collection of the Schmalhausen Institute of Zoology of the National Academy of Sciences of Ukraine, Kiev (SIZK). The amber pieces containing the holotypes were found in the Varash District of Rovno Region (UA-28099) (Yamamoto et al. 2022 and references therein), and in Pugach quarry (Klesov) (fauna of the deposit reviewed in Mitov et al. 2021), Sarny District, Rovno Region (K-9948). The Varash specimen was cut from the big piece, the Klesov specimen is part of an unbiased sample (Perkovsky et al. 2012), bought from the Ukramber factory (Rovno); the raw weight of clear piece 2-1410 was 7.3 $\mathrm{g}$, size $45 \times 25 \times 15 \mathrm{~mm}$.

Photographs were taken using a Leica Z16 APO stereomicroscope equipped with a Leica DFC 450 camera and processed with LAS Core and Adobe Photoshop software (brightness and contrast only). To improve imaging, we applied sucrose syrup of approximately the same refractive index as the amber itself and then placed a glass cover slip on top. To photograph some of the structures, the cover slip was placed at different angles to the surface of the amber (Fig. 1A). Afterwards, the syrup was removed by warm water.

Terminology and abbreviations follow Sharkov (1985), Gibson (1997), and Heraty et al. (2013). The following abbreviations are used in the text: F1, F2, etc. = funicular segments 1, 2, etc.; $\mathbf{L O L}=$ minimum distance between the anterior ocellus and a 
posterior ocellus; Mt1, Mt2, etc. = metasomal terga, numbering starts from petiole $(\mathrm{Mt} 1) ; \mathbf{O O L}=$ minimum distance between an eye margin and the adjacent posterior ocellus; $\mathbf{O C L}=$ minimum distance between a posterior ocellus and the occipital margin; $\mathbf{P O L}=$ minimum distance between the posterior ocelli.

\section{Results}

\section{Systematic paleontology}

\section{Chalcidoidea Latreille, 1817 \\ Encyrtidae Walker, 1837}

\section{Genus Archaeocercoides Simutnik, gen. nov.}

http://zoobank.org/DAE286E2-09CB-438D-A5B7-F467697167DB

Type species. Archaeocercoides puchkovi Simutnik, sp. nov.

Species composition. Type species only.

Etymology. The new genus resembles the extinct genus Archaeocercus Simutnik, 2018 by its extremely apical position of the cerci (Fig. 3B-D, and figs 5, 6 in Simutnik and Perkovsky 2018a). The genus name is a masculine noun.

Diagnosis. Habitus not 'encyrtiform', body not compact, slightly elongated and flattened; minimum distance between eyes almost $0.5 \times$ head width; frontovertex broader than long, ocelli in strongly obtuse triangle, posterior ocelli elliptical in dorsal view; all 6 funicular segments transverse, first funicular segment ring-like; clava only slightly shorter than funicle, about $2.2 \times$ as long as broad; mesoscutum and scutellum flat, notaular lines absent; scutellum as long as broad, flat, and as long as mesoscutum; marginal vein more than three times as long as broad, shorter than postmarginal one; covering setae (sensu Sharkov 1985) along basal margin of linea calva present, poorlydeveloped, but much longer than in Archaeocercus (Fig. 3A: cs and fig. 6 in Simutnik and Perkovsky 2018a); filum spinosum absent; parastigma not widened, only slightly wider than previous part of submarginal vein; strigil poorly developed; cerci located extremely close to gastral apex (Fig. 3B-D); apex of hypopygium reaching way past apex of gaster (Fig. 3B-D), lateral margins of hypopygium with row of short setae (Fig. 3C); ovipositor sheaths very small (supposedly, their rudiments are visible in Fig. 3C, D: v3?); protruding part of ovipositor stylet upwardly bent, approximately as long as mesotarsus (Fig. 3B-D). However, the ovipositor, partly, is in the "laying or ovipositing position". Therefore, when it was not in the ovipositing position, it would be mostly retracted and enclosed within the hypopygium and not really truly exserted. The hypopygium may also slightly not reach to the apex of the gaster.

Remarks. The new genus is very similar to Archaeocercus Simutnik, 2018, but differs by the OOL being equal to the posterior ocellar diameter, the posterior ocelli are relatively larger and elliptical in dorsal view; the clava is more narrow and elongated; 
the parastigma is not expanded (Archaeocercus with distinct parastigma, see figs 1, 2, 6 in Simutnik and Perkovsky 2018a); notauli are absent; the scutellum is longer, as broad as long, not shorter than the mesoscutum; the inner angles of the axillae are wider; the covering setae along linea calva are short but distinctly present; and by its long ovipositor stylet (in the "ovipositing position")(see figs 1-6 in Simutnik and Perkovsky 2018a). Trjapitzion Simutnik, 2018 clearly differs from the new genus in a high interantennal prominence, strongly expanded parastigma, strongly widened scape and mandible, and in very short legs, especially tarsi (figs 2, 3, 6 in Simutnik and Perkovsky 2018b).

\section{Archaeocercoides puchkovi Simutnik, sp. nov.}

http://zoobank.org/50A0A5E5-EFD7-4C7C-AD5B-2B095282C5A9

Figs 1A, B, D, 2, 3

Material. Holotype, SIZK, no. UA-28099, 1ㅇ, Varash District, Rovno Region, Ukraine; Rovno amber; late Eocene. The inclusion is in a yellow and clear piece of amber in a shape of parallelepiped (ca. $40 \times 10 \times 9 \mathrm{~mm})$, one side of which contains a layer of organic residues. All body parts are preserved.

Syninclusion. Crawler of Coccoidea (Fig. 1C, D).

Etymology. The species is named in memory of our colleague coleopterist Prof. Aleksandr Vasilievich Puchkov.

Description. Female. Habitus as in Figs 1B, 2C. Body not compact, slightly elongated and flattened. Body length $1.2 \mathrm{~mm}$.

Coloration. Body, antenna, tegula, gaster dorsally and ventrally black; surface of frontovertex, mesoscutum, scutellum and axillae smooth, shiny, but without metallic shine, monotonously shallow reticulate with sparse punctures, evenly clothed in short setae (Figs 1B, 2A); coxae, and legs black, meso- and metatibia with lighter apices; protarsus dark; mesotibial spur, meso- and metatarsus light brown to yellowish.

Head. Hypognathous, slightly wider than thorax (8:7) in dorsal view, twice as broad as long, with rounded occipital margin; eyes bare, with inner orbits parallel; minimum distance between eyes almost $0.5 \times$ head width; OOL about equal to posterior ocellar diameter (Fig.2A); OCL about equal to half of posterior ocellar diameter; OOL:POL:LOL:OCL about 1:9:5.5:1.5; eye reaching occipital margin; facial cavity and interantennal prominence present but without distinct antennal scrobes (Fig. 2A); toruli located above of mouth margin, about at level of lower margin of eyes (Fig.2B); malar sulcus complete; mandibles, probably two-toothed, with powerful teeth (Fig. 2B).

Antenna. Geniculate, 11-segmented (1:1:6:3); radicle short, about $2-2.5 \times$ as long as broad; scape wide, flattened (Fig. 2A); pedicel conical, slightly shorter than F1-F4 combined, longer than any segment of funicle; funicle cylindrical, all segments broader than long, width of flagellomeres increases toward apex; F4-F6 and all segments of clava with mps (Fig. 2A, B); clava large, only slightly shorter than funicle, about $2.2 \times$ 


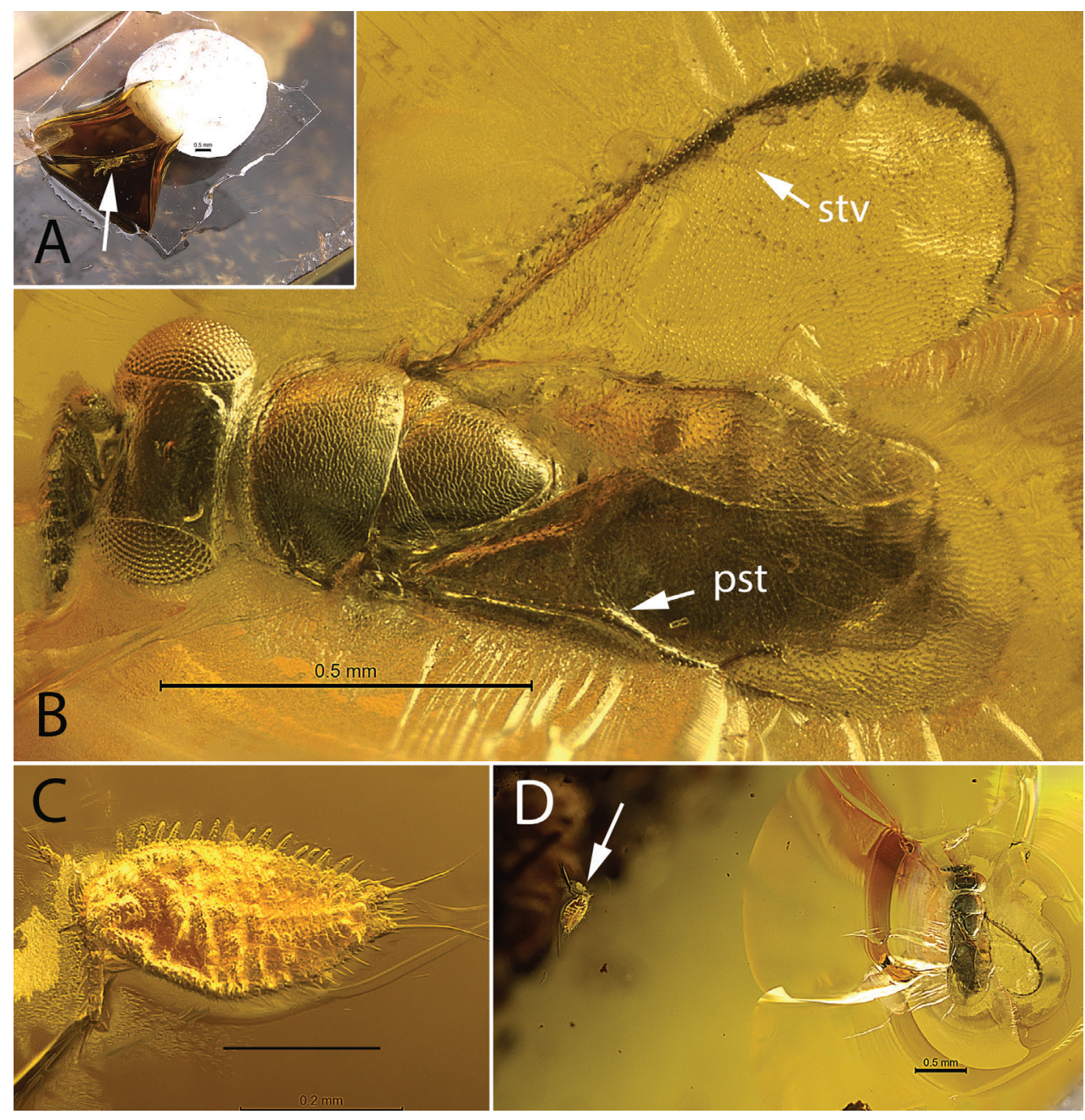

Figure I. A cover slip at some angle to the surface of the amber, the inclusion is shown by an arrow B Archaeocercoides puchkovi, gen. et sp. nov., holotype female, body, dorsal (pst - parastigma, stv - stigmal vein) $\mathbf{C}$ syninclusion, crawler of Coccoidea $\mathbf{D}$ A. puchkovi, gen. et sp. nov., fossilized near the crawler of Coccoidea (arrow). Scale bars: $0.5 \mathrm{~mm}(\mathbf{A}, \mathbf{B}, \mathbf{D}) ; 0.2 \mathrm{~mm}(\mathbf{C})$.

as long as broad, with small oblique truncation on non-acute apical segment (Fig. 2B: ot), slightly wider than F6; flagellum and clava clothed in short setae.

Mesosoma. Pronotum short, almost vertical, in dorsal view without transverse dorsal surface (Fig. 2A); mesoscutum broader than long, flat; axillae transverse-triangular with anteromedial angles contiguous (Fig. 2A); prepectus large, bare, polygonally reticulate, posterior margin extended to base of tegula; acropleuron convex, bare, with shallow longitudinal reticulate sculpture, long, in lateral view twice as long as height (Fig. 2C: ac), with distinct acropleural sulcus; subtegular region (Fig. 2D: str) of acropleuron large, convex, delineated by distinct sulcus; metapleuron narrow, without visible setation (Fig. 2C). 


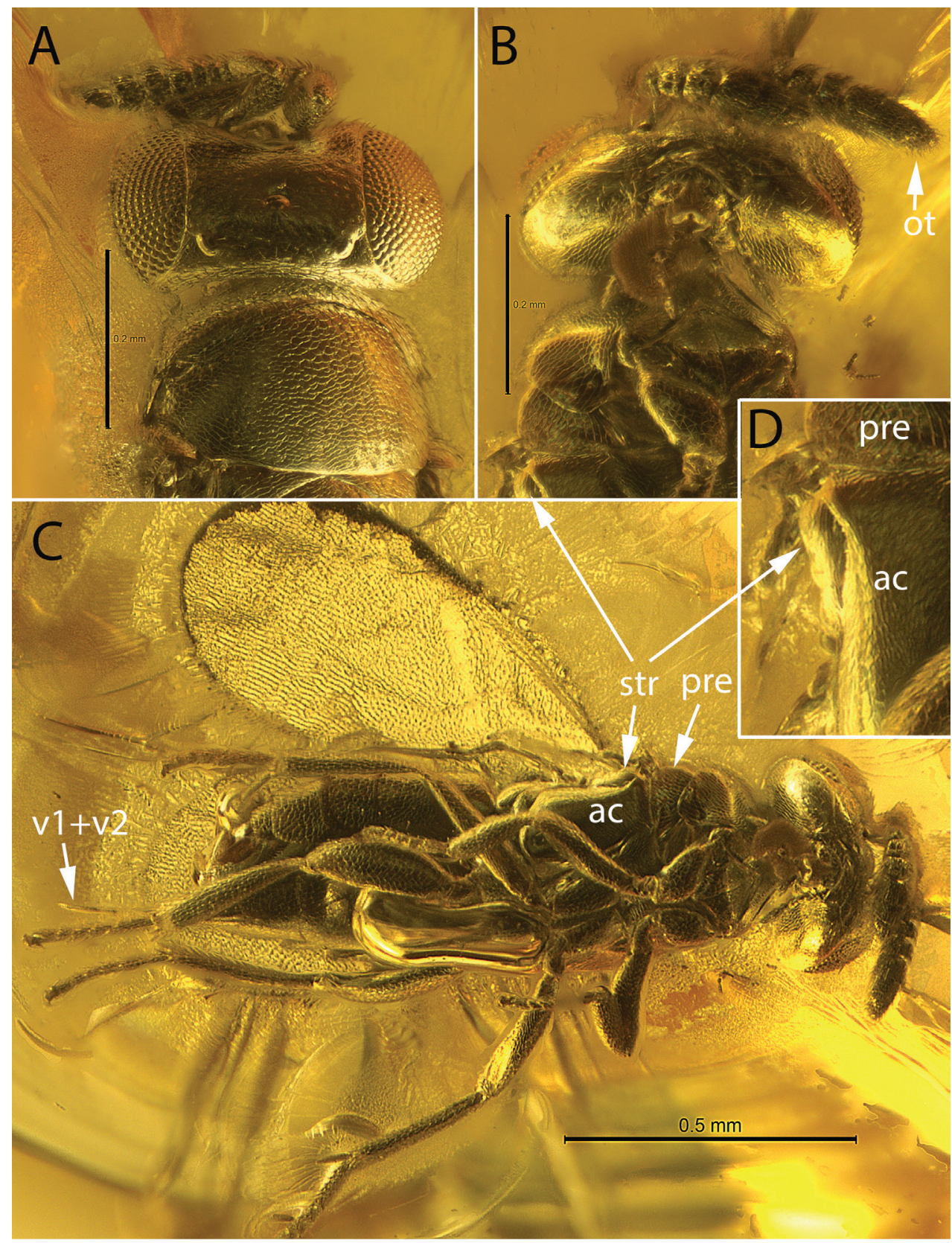

Figure 2. A. puchkovi, gen. et sp.nov., holotype female $\mathbf{A}$ head, mesoscutum, dorsal $\mathbf{B}$ head, anterior part of the mesosoma, ventral (ot - oblique truncation) C body, ventrolateral ( $\mathrm{ac}$ - acropleuron, pre - prepectus, str - subtegular region, v1 + v2 - ovipositor stylet) D subtegular region, ventrolateral. Scale bars: 0.2 $\mathrm{mm}(\mathbf{A}, \mathbf{B}) ; 0.5 \mathrm{~mm}(\mathbf{C})$. 


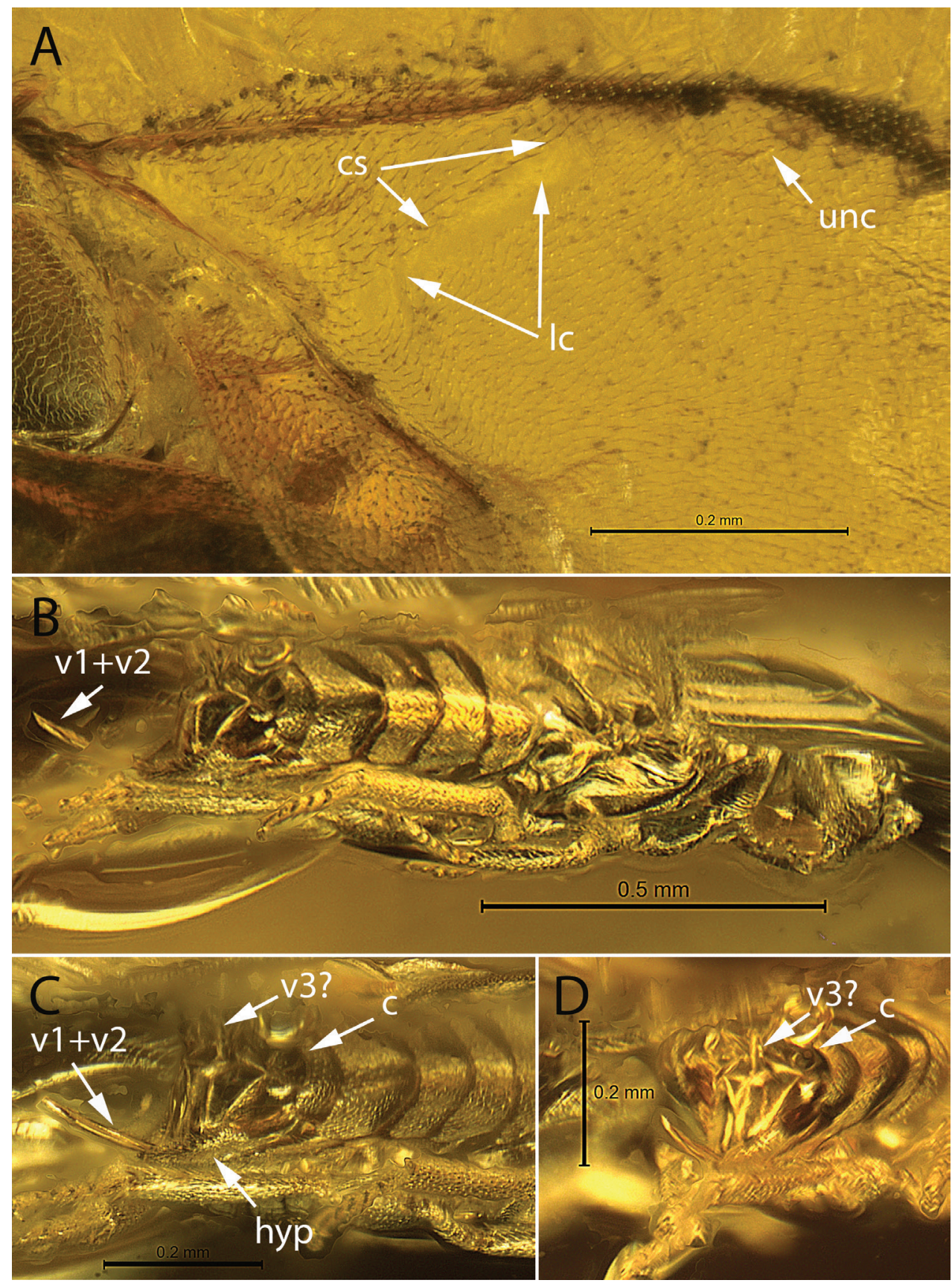

Figure 3. A. puchkovi, gen. et sp. nov., holotype female $\mathbf{A}$ wings (cs - covering setae, lc- linea calva, unc - uncus) B body, lateral (v1 + v2 - ovipositor stylet) $\mathbf{C}$ apex of gaster, lateral (c - cercus, hyp- hypopygium, v3? - supposedly, ovipositor sheath) D apex of gaster, posterolateral. Scale bars: $0.2 \mathrm{~mm}(\mathbf{A}$, C, D); $0.5 \mathrm{~mm}(\mathbf{B})$. 
Wings. Fully developed. Fore wing with basal cell uniformly setose; costal cell narrow; submarginal vein without distinct extension (Fig. 3A), although, when lighting from above, parastigma appears to be somewhat swollen (Fig. 1B: pst); hyaline break (unpigmented area) present; marginal vein long, but slightly shorter than stigmal and postmarginal veins (Fig. 1B, left wing); proportions of forewing venation as in Figs 1B, 2C, 3A; stigmal vein with long narrow uncus, consisting row of uncal sensillae (Fig. 3A: unc); enlarged seta marking apex of postmarginal vein of fore wing rather absent (Fig. 3A); setae of marginal fringe short.

Legs. Normal in size, alike polygonally reticulate; protibia with long, curved calcar; basitarsal comb poorly developed; tarsi 5-segmented; mesotibial spur slightly shorter than mesobasitarsus; metatibia with two spurs.

Gaster. As long as mesosoma, polygonal reticulate equal dorsally and ventrally, apical margins of metasomal terga straight, parallel; paratergites and cercal setae not visible; ovipositor stylet combined from $1^{\text {st }}$ and $2^{\text {nd }}$ valvulae (stylet suture presumably visible in Fig. 3C); hypopygium in Fig. 3B-D: hyp.

Male. Unknown.

\section{Genus Rovnopositor Simutnik, gen. nov.}

http://zoobank.org/45722928-C925-48E9-930F-D5BD9759E370

Type species. Rovnopositor voblenkoi Simutnik, sp. nov.

Species composition. Type species only.

Etymology. The name of the genus is a combination of the words "Rovno" and "ovipositor". The new genus is distinguished by an unusual ovipositor structure. Gender masculine.

Diagnosis. Habitus not 'encyrtiform', body not compact, not flattened; ocelli in almost right angled triangle (Fig. 5B), posterior ocelli elliptical in dorsal view; frontovertex about as long as broad; flagellum long, first funicular segment $1.5 \times$ as long as broad, funicle without transverse segments; clava slightly longer than F4-F6 combined, $2.5 \times$ as long as broad; mesoscutum and scutellum convex, notauli absent; scutellum as broad as long, and as long as mesoscutum; marginal vein relatively short, twice as long as broad, and one-third as long as postmarginal vein; setae along basal margin of linea calva short; filum spinosum absent; parastigma almost not widened; strigil present, well-developed; cerci slightly advanced toward gastral base, with long cercal setae (Fig. 5D: cers); apex of hypopygium reaching way past apex of gaster (in ovipositing position, Fig. 5A,D: hyp), lateral margins of hypopygium bare, without row of setae; protruding part of ovipositor stylet stout, upwardly bent (in ovipositing position); ovipositor sheaths strongly reduced, not visible in lateral view.

Remarks. The new genus differs from Archaeocercoides in the right angled ocellar angle; the frontovertex is about as long as broad; its long flagellum, the first funicular segment being longer than broad, the funicle without transverse segments; the clava slightly longer than F4-F6 combined, $2.5 \times$ as long as broad; the relatively short marginal vein, twice as long as broad and one-third length of postmarginal vein; the 
convex mesoscutum and scutellum; the well-developed strigil; the cerci are noticeably advanced toward the gastral base; the lateral margins of hypopygium are bare; and in its stouter and longer protruding part of the ovipositor stylet (in ovipositing position).

\section{Rovnopositor voblenkoi Simutnik, sp. nov.}

http://zoobank.org/1940BF44-3174-40EE-8DD7-305A9013317C

Figs 4, 5

Material. Holotype, SIZK, no. K-9948, 1 q, Klesov, Sarny District, Rovno Region, Ukraine; Rovno amber; late Eocene. The inclusion is in a reddish and not very transparent piece of amber in a shape of irregular triangular prism (ca. $10 \times 10 \times 15 \times$ $7 \mathrm{~mm}$ ) (Fig. 4B). All body parts are preserved.

Syninclusions. SIZK, no. K-9949, 2 Dolichopodidae, Aranei, stellate hairs.

Etymology. The species is named in memory of our colleague Aleksandr Sergeevich Voblenko, an entomologist, zoologist, naturalist, and teacher.

Description. Female. Habitus as in Fig. 4C. Body not compact, not flattened. Body length $1.25 \mathrm{~mm}$.

Coloration. Body, antennae, gaster dorsally and ventrally dark, without metallic shine, monotonously shallow reticulate; pronotum, mesoscutum, and scutellum clothed in more long setae.

Head. Hypognathous, wider than its length, slightly wider than thorax, with rounded occipital margin (Fig. 5B); eyes bare, with inner orbits rather slightly divergent (Fig. 4D); OOL equal to posterior ocellar diameter; OCL about twice as long as posterior ocellar diameter; eye reaching occipital margin; interantennal projection small but visible in lateral view (Fig. 4A); toruli located at level of lower margin of eyes (Fig. 4A); malar sulcus complete; height of eye about twice larger than malar space; mandibles narrow, probably two-toothed (Figs 4A, C; 5A).

Antenna. 11-segmented (1:1:6:3); radicle short, twice as long as broad; scape long, about $5 \times$ as long as broad (Fig. 4A); pedicel conical, as long as F1 and F2 combined, longer than any segment of funicle; funicle not flattened, width of flagellomeres slightly increases toward apex; all segments of funicle and clava with mps (Fig. 4A); clava with small oblique truncation on rounded apical segment (Fig. 4A), slightly wider than F6; flagellum and clava clothed in short setae.

Mesosoma. Pronotum short, almost vertical, in dorsal view without transverse dorsal surface (Fig. 5B); mesoscutum about as broad as long; axillae transverse-triangular with anteromedial angles contiguous; prepectus large, bare, polygonally reticulate (Fig. 5B); acropleuron convex, bare, with shallow longitudinal reticulate sculpture, long; subtegular region of acropleuron large, convex, delineated by distinct sulcus; metapleuron and propodeum without visible setation (Fig. 4C).

Wings. Fully developed. Fore wing with costal cell narrow; submarginal vein without extension; hyaline break present; setation of linea calva in holotype poorly visible (Fig. 5C); marginal vein $0.5 \times$ as long as stigmal one; proportions of forewing venation as in Fig. 5C; stigmal vein with long narrow uncus, consisting row of uncal 

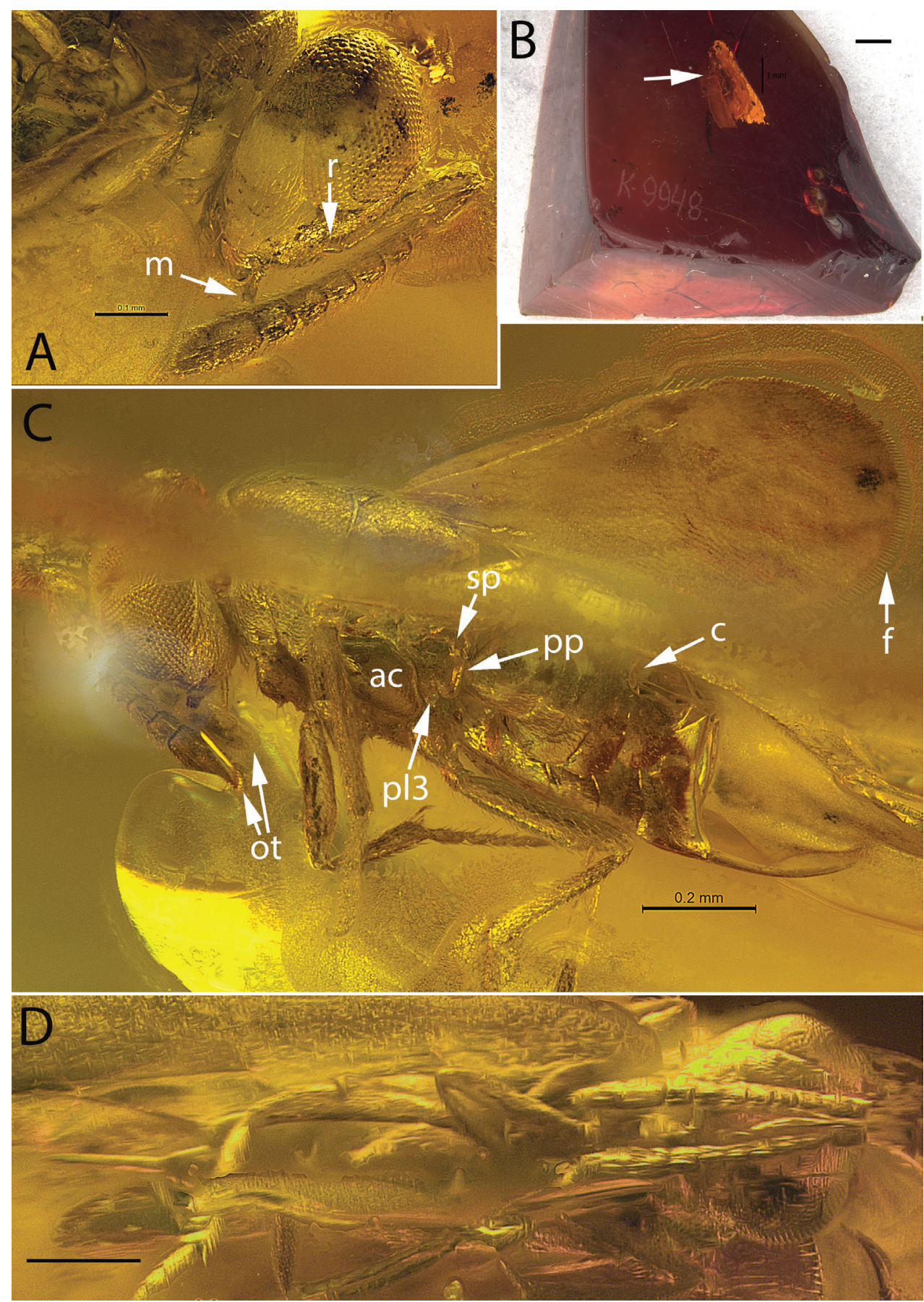

Figure 4. Rovnopositor voblenkoi gen. et sp. nov., holotype female $\mathbf{A}$ head, antenna, lateral ( $\mathrm{m}-$ mandible, $r$ - radicle) B piece of amber with holotype (arrow) C body, dorsolateral (ac - acropleuron, $\mathrm{c}-\mathrm{cercus,}$ $\mathrm{f}$ - marginal fringe, ot - oblique truncation, $\mathrm{pl}$ - metapleuron, $\mathrm{pp}$ - prepectus, sp - spiracle) $\mathbf{D}$ body, ventral. Scale bars: $0.1 \mathrm{~mm}(\mathbf{A}) ; 1 \mathrm{~mm}(\mathbf{B}) ; 0.2 \mathrm{~mm}(\mathbf{C}, \mathbf{D})$. 


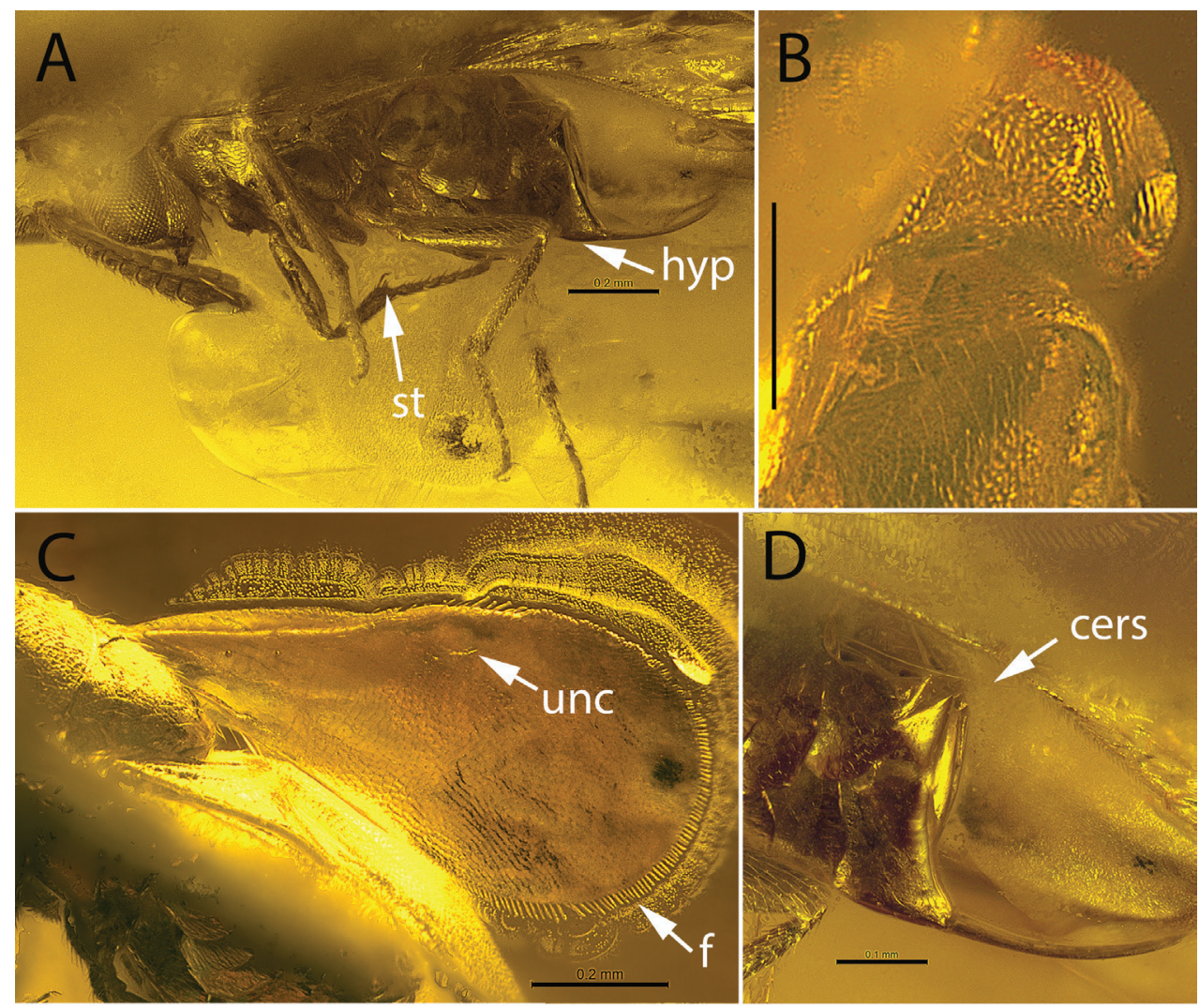

Figure 5. R. voblenkoi, gen. et sp. nov., holotype female $\mathbf{A}$ body, lateral (hyp - hypopygium, st - strigil) $\mathbf{B}$ head, anterior part of the mesosoma, dorsolateral $\mathbf{C}$ forewing ( $\mathrm{f}$ - marginal fringe, unc - uncus) $\mathbf{D}$ apex of gaster, lateral (cers - cercal setae). Scale bars: $0.2 \mathrm{~mm}(\mathbf{A}-\mathbf{C}) ; 0.1 \mathrm{~mm}(\mathbf{D})$.

sensillae; postmarginal vein with row of long setae; setae of marginal fringe present (Fig. 5C).

Legs. Normal in size, alike polygonal reticulate; protibia with long, curved, bifurcate calcar; strigil well-developed but distinct basitarsal comb absent (Figs 4C, 5A: st); tarsi 5-segmented; mesotibial spur slightly shorter than mesobasitarsus; metatibia with two spurs.

Gaster. As long as mesosoma, polygonal reticulate equal dorsally and ventrally; protruding part of ovipositor stylet approximately as long as metatarsus (in ovipositing position); suture between $1^{\text {st }}$ and $2^{\text {nd }}$ valvulae clearly visible at base and at apex of stylet (Fig. 5D).

Male. Unknown.

\section{Discussion}

The new genera differ from most extant members of the family by their short radicle, long veins of the forewing, and by the apical position of the cerci. A more detailed 
comparison with extant genera with apical or nearly apical position of the cerci is provided by Simutnik 2021; Simutnik et al. 2021a, 2021b. In particular, extant Eucoccidophagus Hoffer, 1963; Aphycoides Mercet, 1921; and Prionomastix Mayr, 1876 are well distinguished from the all known extinct genera by having a very short marginal vein. Archaeocercoides, Rovnopositor, and Archaeocercus also differ from Aphycoides and Prionomastix in the absence of a filum spinosum and the shape of Mt8 (fig. 12C in Simutnik 2021 and fig. 9 in Simutnik et al. 2021b).

The venation of the forewings and the very small ovipositor sheaths in the newly described taxa most closely resemble those of Moraviella Hoffer, 1954; Monodiscodes Hoffer, 1954; Savzdargia Trjapitzin, 1979; possible, some species of Ericydnus Walker, 1837; and some other extant Tetracneminae. Savzdargia may be the "most primitive" extant Tetracnemine (Trjapitzin 1989; Noyes and Hayat 1994; J. S. Noyes pers. comm., 2022). At the same time, the paratergites (the presence of which is one of the main features of Tetracneminae) has not yet been found in fossil encyrtids, including the taxa described here. Tetracneminae is probably a more derived group - it always comes out as a derived group in DNA based phylogenetic analyses (J. S. Noyes pers. comm., 2022). Therefore, it would be premature to classify Archaeocercus, Archaeocercoides, Rovnopositor and other known fossil Encyrtidae without the filum spinosum as members of the Tetracneminae within the current concept of this subfamily. Their taxonomic placement within the family remains uncertain.

\section{Acknowledgements}

We are grateful to John S. Noyes, Alexandr P. Rasnitsyn, S. Bruce Archibald for their help, valuable comments, and discussion, and to A.P. Vlaskin (SIZK) for cutting and polishing the sample. The authors are thankful to the editor Petr Janšta. This work was supported by grants NRFU No. 2020/02/0369 (to S.A. Simutnik).

\section{References}

Belokobylskij SA, Pankowski MG, Pankowski MV,Zaldívar-Riverón A (2021) A new genus and three new species of fossil braconid wasps (Hymenoptera, Ichneumonoidea) from Eocene Baltic and Rovno ambers. Journal of Paleontology 95(6): 1259-1272. https://doi.org/10.1017/jpa.2021.47

Colombo WD, Gobbi FT, Perkovsky EE, Azevedo CO (2021a) Synopsis of the fossil Pristocerinae (Hymenoptera, Bethylidae), with description of two new genera and six species from Burmese, Taimyr, Baltic and Rovno ambers. Historical Biology 33(9): 1736-1752. https:// doi.org/10.1080/08912963.2020.1733551

Colombo WD, Perkovsky EE, Vasilenko DV (2021b) The first sclerodermine flat wasp (Hymenoptera: Bethylidae) from upper Eocene Rovno amber, Ukraine. Alcheringa 45(4): 429-434. https://doi.org/10.1080/03115518.2021.2006311

Colombo WD, Perkovsky EE, Waichert C, Azevedo CO (2021c) Synopsis of the fossil flat wasps Epyrinae (Hymenoptera, Bethylidae), with description of three new genera and 10 
new species, Journal of Systematic Palaeontology 19(1): 39-89. https://doi.org/10.1080/ 14772019.2021 .1882593

Gibson GAP (1997) Chapter 2. Morphology and terminology. In: Gibson GAP, Huber JT, Woolley JB (Eds) Annotated keys to the genera of Nearctic Chalcidoidea (Hymenoptera). NRC Research Press, Ottawa, 16-45. [794 pp.]

Giłka W, Harbach RE, Perkovsky EE (2021) Mosquitoes (Diptera: Culicidae) in Eocene amber from the Rovno region, Ukraine. Zootaxa 5016 (2): 257-270. https://doi:10.11646/ zootaxa.5016.2.6

Heraty JM, Burks RA, Cruaud A, Gibson GA, Liljeblad J, Munro J, Rasplus JY, Delvare G, Janšta P, Gumovsky A, Huber JT, Woolley JB, Krogmann L, Heydon S, Polaszek A, Schmidt S, Darling DC, Gates MW, Mottern J, Murray E, Dal Molin A, Triapitsyn S, Baur H, Pinto JD, van Noort S, George J, Yoder M (2013) A phylogenetic analysis of the megadiverse Chalcidoidea (Hymenoptera). Cladistics 29: 466-542. https://doi.org/10.1111/cla.12006

Kirichenko-Babko M, Perkovsky EE, Vasilenko DV (2022) †Antephilorhizus zerovae sp. nov. (Carabidae: Lebiini), the second ground beetle species from Rovno amber. Historical Biology. https://doi.org/10.1080/08912963.2021.2018686

Manukyan AR (2019) New data on ichneumon wasps of the subfamily Pherhombinae (Hymenoptera, Ichneumonidae) in Baltic amber with descriptions of three new species. Entomological Review 99(9): 1324-1338. https://doi.org/10.1134/S0013873819090112

Manukyan AR, Zhindarev LA (2021) Fossil Darwin wasps (Hymenoptera: Ichneumonidae) from Baltic amber. Palaeoentomology 4(6): 637-647. https://doi.org/10.11646/palaeoentomology.4.6.13

Martynov AV, Vasilenko DV, Perkovsky EE (2021) First Odonata from Upper Eocene Rovno amber (Ukraine). Historical Biology. https://doi.org/10.1080/08912963.2021.2005040

Martynova KV, Perkovsky EE, Olmi M, Vasilenko DV (2019) New records of Upper Eocene chrysidoid wasps (Hymenoptera: Chrysidoidea) from basins of Styr and Stokhod rivers (Rovno amber). Paleontological Journal 53(10): 998-1023. https://doi.org/10.1134/ S0031030119100125

Melnitsky SI, Ivanov VD, Perkovsky EE (2021a) A new species of Plectrocnemia (Trichoptera: Polycentropodidae) from Rovno amber. Zootaxa 5006(1): 106-109. https://doi:10.11646/ zootaxa.5006.1.14

Melnitsky SI, Ivanov VD, Perkovsky EE (2021b) A new species the fossil genus Electrotrichia (Insecta: Trichoptera: Hydroptilidae) from Rovno amber (Zhytomyr region, Olevsk amber locality). Palaeoentomology 4(5): 421-424. https://doi.org/10.11646/palaeoentomology.4.5.4

Melnitsky SI, Ivanov VD, Perkovsky EE (2021c) A new species of the genus Holocentropus (Trichoptera: Polycentropodidae) from Rovno amber. Zoosystematica Rossica 30: 298302. https://doi.org/10.31610/zsr/2021.30.2.298

Mitov PG, Perkovsky EE, Dunlop JA (2021) Harvestmen (Arachnida: Opiliones) in Eocene Rovno amber (Ukraine). Zootaxa 4984(1): 43-72. https://doi.org/10.11646/zootaxa.4984.1.6

Noyes JS, Hayat M (1994) Oriental mealybug parasitoids of the Anagyrini (Hymenoptera: Encyrtidae). Wallingford. Oxon: CAB International, [viii +] 554 pp.

Perkovsky EE (2017) Rovno amber caddisflies (Insecta, Trichoptera) from different localities, with information about three new sites. Vestnik zoologii 51(1): 15-22. https://doi. org/10.1515/vzoo-2017-0003 
Perkovsky EE (2018) Only a half of species of Hymenoptera in Rovno amber is common with Baltic amber. Vestnik zoologii 52(5): 353-360. https://doi.org/10.2478/vzoo-2018-0037

Perkovsky EE, Odnosum VK, Nazarenko VY, Vasilenko DV (2022) First record of the genus Cyrtanaspis Emery (Insecta: Coleoptera: Scraptiidae) from Baltic amber. Paleontological Journal 56(2). In press. https://doi.org/10.1134/S0031030122020101

Perkovsky EE, Rasnitsyn AP, Vlaskin AP, Rasnitsyn SP (2012) Contribution to the study of the structure of amber forest communities based on analysis of syninclusions in the Rovno Amber (Late Eocene of Ukraine). Paleontological Journal 46(3): 293-301. https://doi. org/10.1134/S0031030112030136

Sharkov AV (1985) Encyrtids (Hymenoptera, Chalcidoidea, Encyrtidae) of the southern Far East of the USSR [dissertation]. Extended Abstract of Cand. Sci. (Biol.). Leningrad. [in Russian]

Simutnik SA (2021) The earliest Encyrtidae (Hymenoptera, Chalcidoidea). Historical Biology 33(11): 2931-2950. https://doi.org/10.1080/08912963.2020.1835887

Simutnik SA, Perkovsky EE (2006) A description of the encyrtoid male with archaic structure of metasoma (Hymenoptera, Chalcidoidea, Encyrtidae) from Rovno amber. Vestnik Zoologii 40(6): 283-286. http://www.v-zool.kiev.ua/pdfs/2006/3/12

Simutnik SA, Perkovsky EE (2018a) Archaeocercus gen. nov. (Hymenoptera, Chalcidoidea, Encyrtidae) from late Eocene Rovno amber. Zootaxa 4441(3): 543-548. https://doi.org/10. 1080/08912963.2020.1835887

Simutnik SA, Perkovsky EE (2018b) Trjapitzion Simutnik, gen. n. (Hymenoptera, Chalcidoidea: Encyrtidae), a new genus of encyrtid wasps from the late Eocene Rovno amber. Entomological Review 98(8): 1152-1156. https://doi.org/10.1134/S0013873818080225 Simutnik SA, Perkovsky EE (2020) Ektopicercus Simutnik gen. nov. (Hymenoptera, Chalcidoidea, Encyrtidae) from late Eocene Rovno amber. Palaeoentomology 3(4): 342-346. https://doi.org/10.11646/palaeoentomology.3.4.3

Simutnik SA, Perkovsky EE, Vasilenko DV (2020) First record of Leptoomus janzeni Gibson (Hymenoptera, Chalcidoidea) from Rovno amber. Journal of Hymenoptera Research 80: 137-145. https://doi.org/10.3897/jhr.80.58882

Simutnik SA, Perkovsky EE, Vasilenko DV (2021a) Sakhalinencyrtus leleji Simutnik gen. et sp. nov. of earliest Encyrtidae (Hymenoptera, Chalcidoidea) from Sakhalinian amber. Journal of Hymenoptera Research 84: 361-372. https://doi.org/10.3897/jhr.84.66367

Simutnik SA, Perkovsky EE, Khomych MR, Vasilenko DV (2021b) First record of the Sulia glaesaria Simutnik, 2015 (Hymenoptera, Chalcidoidea, Encyrtidae) from Rovno amber. Journal of Hymenoptera Research 88: 85-102. https://doi.org/10.3897/jhr.88.75941

Telnov D, Perkovsky EE, Vasilenko DV, Yamamoto S (2021) The first fossil Coleoptera record from the Volyn Region, Ukraine, with description of a new Glesoconomorphus (Coleoptera, Mycteridae) in syninclusion with Winterschmidtiidae (Acari) and a key to species. ZooKeys 1068: 189-201. https://doi.org/10.3897/zookeys.1068.75391

Trjapitzin VA (1989) Parasitic Hymenoptera of the fam. Encyrtidae of Palaearctics. Opredeliteli po faune SSSR izdavavaemiye Zoologicheskim institutom AN SSSR 158: 1-489. [in Russian]

Yamamoto S, Nazarenko VY, Vasilenko DV, Perkovsky EE (2022) First fossil species of ship-timber beetles (Coleoptera: Lymexylidae) from Eocene Rovno amber (Ukraine). Fossil Record 25(1): 65-74. https://doi.org/10.3897/fr.25.81054 